\title{
Supervisi Administrasi Untuk Meningkatkan Kinerja Guru Dalam Menyusun Perangkat Pembelajaran
}

\author{
Sri Winarni
}

Guru SDN 1 Pandean

Email: sri.winarni@gmail.com

\begin{tabular}{l}
\hline Tersedia Online di \\
http://www.jurnal.unublitar.ac.id/ \\
index.php/briliant
\end{tabular}

Sejarah Artikel

Diterima pada 29 Juni 2017

Disetuji pada 14 Juli 2017

Dipublikasikan pada: 2 Agustus

2017 Hal 335-343

Kata Kunci:

Supervisi administrasi, kinerja guru, perangkat.

\begin{abstract}
Abstrak: Tujuan penelitian ini adalah untuk mengetahui gambaran objektif tentang peningkatan kinerja guru dalam menyusun perangkat pembelajaran melalui supervisi administrasi pada guru kelas IV,V dan VI SDN 1 Pandean Kecamatan Dongko Semster II Tahun Pelajaran 2016/2017. Pelaksanaan supervisi kepala sekolah di SD Negeri 1 Pandean membantu menjelaskan permasalahan bagaimana pelaksanaan supervisi administrasi guru kelas dapat meningkatkan kinerja guru kelas IV, V dan VI di SD Negeri 1 Pandean. Supervisi administrasi guru kelas akan meningkatkan kinerja guru dalam penyusunan administrasi guru kelas.
\end{abstract}

Pasal 3 Undang-undang Nomor 20 tahun 2003 tentang Sistem Pendidikan Nasional menjelaskan bahwa Pendidikan nasional berfungsi mengembangkan kemampuan dan membentuk watak serta peradaban bangsa yang bermartabat dalam rangka mencerdaskan kehidupan bangsa, bertujuan untuk berkembangnya potensi peserta didik agar menjadi manusia yang beriman dan bertakwa kepada Tuhan Yang Maha Esa, berakhlak mulia, sehat, berilmu, cakap, kreatif, mandiri, dan menjadi warga negara yang demokratis serta bertanggung jawab. Kepala sekolah adalah kunci sukses dan tidaknya pelaksanaan proses pendidikan karena pelaksana manajerial sekaligus leader dalam organisasi sekolah adalah kepala sekolah. Kepala sekolah sebagai leader harus memiliki karakter khusus yang mencakup kepribadian, keahlian dasar, pengalaman dan pengetahuan professional, serta mengetahui administrasi dan kepengawasan. Kepala sekolah senantiasa melibatkan staf dalam melaksanakan kegiatan yang berhubungan dengan sekolah agar hasilnya bisa dipertanggungjawabkan serta memuaskan semua pihak, Mulyasa (2009:115). Keberadaan kepala sekolah sebagai kunci sukses pelaksanaan proses pendidikan harus mampu memahami fungsi dan tugas serta tanggung jawab yang melekat yaitu, fungsi edukator, manajer, administrator, supervisor, leader, inovator, dan motivator.

Supervisi adalah suatu kegiatan yang dilakukan oleh pejabat atasan (pengawas atau kepala sekolah) terhadap bawahan (guru dan staf), dalam rangka memberikan bantuan kepada guru dan staf untuk memperbaiki situasi belajar mengajar/kinerja guna meningkatkan mutu pembelajaran (Arikunto (2006:19). Purwanto menekankan bahwa supervisi harus memenuhi prinsip- 
prinsip supervisi bersifat memberikan bimbingan dan memberikan bantuan kepada guru dan staf lain untuk mengatasi masalah dan mengatasi kesulitan, dan bukan mencari-cari kesalahan; pemberian bantuan dan bimbingan dilakukan secara langsung, artinya bahwa bimbingan dan bantuan tersebut tidak diberikan secara langsung tetapi harus diupayakan agar pihak yang bersangkutan tanpa disangka atau dibukakan hatinya dapat merasa sendiri serta sepadan dengan kemampuan untuk dapat mengatasi sendiri; apabila pengawas atau kepala sekolah merencanakan akan memberikan saran atau umpan balik, sebaiknya disampaikan sesegera mungkin agar tidak lupa; kegiatan supervisi sebaiknya dilakukan secara berkala, suasana yang terjadi selama supervisi berlangsung hendaknya mencerminkan adanya hubungan yang baik antara supervisor dan yang disupervisi; dan supervisor membuat catatan singkat, berisi hal-hal penting yang diperlukan untuk membuat laporan, Purwanto (2009:17)

Supervisi dilakukan sebagai kontrol agar kegiatan pendidikan di sekolah terarah pada tujuan yang telah ditetapkan. Supervisi juga dilakukan dalam rangka membantu guru-gurunya untuk mengatasi kesulitan-kesulitan yang ditemui pada saat pembelajaran agar tercipta pembelajaran yang lebih bermutu, yakni pembelajaran yang sesuai dengan apa yang tertuang dalam rencana pelaksanaan pembelajaran yang telah dibuat oleh guru. Arikunto (2006:40) menjelaskan bahwa supervisi penting untuk dilaksanakan dalam rangka meningkatkan mutu pendidikan dan pengajaran pada umumnya dan proses belajar pada khususnya.

Sesuai dengan Permendiknas RI Nomor 13 Tahun 2007 Tentang Standar Kompetensi Kepala Sekolah/Madrasah menyatakan salah satu kompetensi yang harus dimiliki oleh kepala sekolah adalah mampu melaksanakan supervisi. Sebagai seorang supervisor, dalam melaksanakan tugasnya, terdapat empat hal yang tidak boleh diabaikan, yaitu (1) membuat perencanaan program supervisi; (2) melaksanakan program supervisi; (3) mengadakan evaluasi; (4) menindaklanjuti hasil temuan supervisi. Guru, orang yang bertanggung jawab langsung dalam upaya mewujudkan apa yang tertuang dalam perencanaan pembelajaran karena guru yang menyusun dan langsung melaksanakan perencanaan pembelajaran tersebut di kelas. Jika tanpa pengawasan yang berkesinambungan, seringkali tanggungjawab tersebut terabaikan. Kegiatan guru dalam proses pembelajaran tidak terdeteksi kekurangan yang ada serta tidak mempunyai motivasi untuk berinovasi. Variasi pengalaman belajar yang diberikan kepada siswapun sangatlah minim sehingga minat belajar siswa menjadi berkurang, Arikunto (2006:5).

Tugas yang harus dijalankan oleh seorang pemimpin dan supervisor dalam perspektif manajemen salah satunya adalah berusaha memotivasi setiap individu yang dipimpinya agar memiliki motivasi yang kuat dalam melaksanakan setiap tugas dan pekerjaannya, sehingga pada gilirannya dapat dihasilkan kinerja yang unggul. Sedangkan fungsi dari supervisi menurut Arikunto (2006: 13-14) ada tiga yaitu meningkatkan mutu pembelajaran, memicu unsur yang terkait dengan pembelajaran, dan membina dan memimpin. Purwanto (2009:120) teknik supervisi yaitu teknik perseorangan dan teknik kelompok. Teknik perseorangan 
maksudnya ialah supervisi yang dilakukan secara perseorangan, kegiatan yang dapat dilakukan mengadakan kunjungan kelas (classroom visitation), mengadakan kunjungan observasi (observation visits), membimbing guru-guru tentang caracara mempelajari pribadi siswa dan atau mengatasi problema yang dialami siswa, membimbing guru-guru dalam hal-hal yang berhubungan dengan pelaksanaan kurikulum sekolah antara lain: menyusun program semester, menyusun atau membuat program satuan pelajaran, mengorganisasi kegiatan-kegiatan pengelolaan kelas, melaksanakan teknik-teknik evaluasi pengajaran, menggunakan media dan sumber dalam proses belajar mengajar, mengorganisasi kegiatan-kegiatan siswa dalam bidang ekstrakurikuler, study tour, dan sebagainya. Teknik kelompok adalah supervisi yang dilakukan secara kelompok dengan mengadakan pertemuan atau rapat (meetings).

Berpedoman kepada pendekatan, pandangan dan keterampilan supervisi pembelajaran ini, supervisor dapat mengaksentuasikan supervisinya terhadap aspek-aspek substantif supervisi pembelajaran. Aspek-aspek substantif tersebut meliputi supervisi terhadap keterampilan mengajar guru, supervisi terhadap kepuasan kerja guru, dan supervisi terhadap disiplin kerja guru. Aspek pertama dan kedua bersentuhan dengan segi profesionalitas guru, sedangkan aspek ketiga, keempat, dan kelima bersentuhan dengan aspek personal guru. Kepala Sekolah memiliki tugas dan tanggung jawab, serta wewenang yang berat dalam rangka mengelola sekolah. Keberhasilan sekolah yang dipimpinnyasangat ditentukan oleh kepemimpinannya. Supervisi merupakan peran yang strategis bagi kepala sekolah dalam melakukan fungsi manajemen dalam pengawasan (controlling), pembinaan dan pengembangan (development) bagi anggota organisasi. Kepala Sekolah sebagai pimpinan dalam menjalankan fungsinya perlu efektif dan efesien. Dalam hal ini, selama proses aktivitas organisasi sekolah tersebut dilakukan, maka kepala sekolah dituntut untuk dapat menjalankan supervisi sebagai salah satu peran strategisnya dalam melakukan pengelolaan sekolah. Efektif berarti dampak positif yang dihasilkan dari melaksanakan supervisi, yang ditunjukkan dengan peningkatan kemampuan dalam organisasi.

Bertitik tolak dari penjelasan di atas, maka peneliti merasa yakin bahwa dengan melakukan supervisi yang dilaksanakan secara efektif dan berkesinambungan, maka kinerja dapat lebih meningkat. Melalui kegiatan supervisi para guru akan berupaya meningkatkan kemampuan dan keterampilan profesinya sehingga dapat meningkatkan kualitas pembelajaran di kelas. Supervisi yang dilakukan secara tepat dan berkesinambungan dapat meningkatkan dedikasi guru terhadap tugas yang harus dikerjakan sebagai seorang pendidik dan pembelajar.

\section{METODE}

Jenis penelitian yang dilakukan adalah penelitian tindakan sekolah. Alasannya karena pendekatan penelitian tindakan sekolah dalam penelitian ini adalah pertimbangan bahwa data yang akan dikumpulkan merupakan data yang diperoleh berdasarkan observasi yang wajar, apa adanya, dan tanpa dipengaruhi dengan sengaja (alamiah). Pengumpulan data yaitu dengan kegiatan wawancara 
dengan narasumber, observasi dan mencari dokumen-dokumen yang diperlukan. Data yang diperoleh peneliti selanjutnya dituangkan dalam bentuk laporan dan uraian.

Lokasi penelitian dalam penelitian ini adalah Sekolah Dasar Negeri 1 Pandean yang ada di Kecamatan Dongko, penelitian dilakukan di Sekolah Dasar Negeri. Subjek penelitian dalam penelitian ini adalah guru kelas IV, V dan VI. Peneliti mengambil permasalahan peningkatan kinerja dalam menyusun perangkat administrasi guru kelas sebagai objek penelitian. Sumber pada penelitian ini adalah kepala sekolah dan guru. Peneliti memilih guru kelas Iv, V dan VI yang dianggap kompeten untuk dijadikan narasumber utama (key informant) peningkatan kinerja dalam menyusun perangkat administrasi guru kelas.

Data diperoleh dengan mengadakan observasi situasi dan wawancara dengan responden. Data yang diambil dari dokumen-dokumen yang ada di tempat penelitian guna melengkapi informasi-informasi yang diperoleh melalui observasi dan wawancara. Penelitian ini lebih mengutamakan dokumen-dokumen yang ada di lembaga di mana penelitian ini dilaksanakan. Prosedur Penelitian, siklus I dan siklus II memiliki tahapan yang sama yakni proses pelaksanaan siklus menempuh empat tahapan, yakni: (1) perencanaan, (2) pelaksanaan, (3) observasi, dan (4) refleksi.

Teknik analisis data dalam penelitian ini menggunakan model analisis Miles and Huberman (1984), yang mengatakan bahwa aktivitas dalam analisis data kualitatifdilakukan secara interaktif dan berlangsung becara terus menerus sampai tuntas.sehingga datanya sudah jenuh. Aktivitas dalam analisis data, yaitu data deduction, data display, dan conclusion drawing/verification. Adapun langkah -langkahnya sebagai berikut: data reduction (reduksi data), yakni semua data yang berhasil dikumpulkan kemudian direduksi/dirangkum untuk mendapatkan data yang sesuai, data yang tidak sesuai tidak digunakan (dibuang), karena dianggap tidak penting bagi peneliti; data display (penyajian data), yakni data yang telah direduksi, dikelompokkan sesuai dengan kategorinya, masing-masing kelompok data yang sudah sesuai (sejenis) disusun untuk ditampilkan agar dapat dicerna dan dipahami, sehingga permasalahan yang ada menjadi tampak; dan dan conclusion drawing/verification, yaitu peneliti berusaha mencari makna terhadap data yang diperoleh sejak awal penelitian. Kesimpulan akan mulai dirumuskan sejak memperoleh data. Meskipun kesimpulan itu masih bersifat sementara, dan akan berubah bila tidak ditemukan bukti-bukti yang kuat yang mendukung pada tahap pengumpulan data berikutnya. Tetapi apabila kesimpulan yang dikemukakan pada tahap awal, didukung oleh bukti-bukti yang valid dan konsisten saat peneliti kembali ke lapangan mengumpulkan data, maka kesimpulan yang dikemukakan merupakan kesimpulan yang kredibel.

Indikator keberhasilan dalam pelaksanaan kegiatan penelitian tindakan sekolah ini didasarkan pada hasil observasi yang dilakukan terhadap kelengkapan administrasi yang dimiliki oleh masing-masing guru kelas. Penilaian didasarkan pada kriteria guru secara individual dan klasikal dinyatakan telah meningkat kinerjanya dalam menyusun perangkat administrasi guru kelas bila minimal memperoleh nilia $>=141$ dan dengan predikat BAIK. 
HASIL

\section{Kondisi Awal}

Rendahnya kualitas perangkat administrasi guru kelas yang ada di SDN 1 Pandean dibuktikan dari hasil observasi dan wawancara terhadap tiga orang guru yaitu guru kelas IV, V dan VI, diperoleh informasi bahwa hasil observasi pada kondisi awal 3 orang guru atau 100\% dinyatakan belum mampu melaksanakan penyusunan administrasi kelas dengan benar. Secara klasikal kemampuan guru dalam melaksanakan kegiatan penyusunan administrasi kelas belum memenuhi kriteria keberhasilan, karena baru memperoleh angka 78 dengan kriteria KURANG, menunjukkan perolehan hasil masih berada di bawah kriteria keberhasilan yaitu minimal mendapat skor 141 atau lebih dengan kriteria minimal BAIK.

\section{Siklus I}

Proses pelaksanaan siklus I menempuh empat tahapan, yakni: (1) perencanaan, (2) pelaksanaan, (3) observasi, dan (4) refleksi. Observasi dilakukan sejak awal hingga akhir menggunakan lembar observasi yang telah disediakan. Berdasarkan hasil observasi diperoleh beberapa catatan serta hasil penilaian terhadap kemampuan masing-masing guru. Dari hasil analisis dapat dijabarkan bahwa pada pelaksanaan siklus pertama, walaupun mengalami peningkatan yang cukup signifikan dari kondisi awal, tetapi masih belum menunjukkan hal yang maksimal sesuai dengan harapan. Secara klasikal peningkatan kemampuan guru dalam melaksanakan kegiatan penyusunan administrasi kelas belum memenuhi criteria keberhasilan, karena baru memperoleh angka 118 dengan kriteria CUKUP. Hal ini menunjukkan bahwa perolehan hasil tersebut masih berada di bawah kriteria keberhasilan yaitu minimal mendapat skor 141 atau lebih dengan kriteria minimal BAIK.

\section{Siklus II}

Proses pelaksanaan pada siklus II dilakukan dengan tahapan (1) perencanaan, (2) pelaksanaan, (3) observasi, dan (4) refleksi untuk memperbaiki kajian pada siklus I.

\section{Perencanaan}

Tindakan perencanaan tindakan siklus II ini dilakukan atas dasar hasil refleksi siklus I meliputi supervisi administrasi guru kelas pada siklus II ditujukan pada upaya pemulihan pemahaman guru SD Negeri 1 Pandean terhadap hal-hal yang kurang mampu dipenuhi, baik terkait dengan beberapa komponen perencanaan pembelajaran maupun tahapan-tahapan penting dalam melaksanakan pembelajaran yang didasarkan pada suatu model pembelajaran terpilih sebagai dasar dalam menentukan penyusunan administrasi kelas siswa; supervisi administrasi guru kelas siklus II dilaksanakan pada bulan Februari 2017.

Waktu yang direncanakan untuk masing-masing guru, pada tanggal 22 Februari 2017, supervisi administrasi guru kelas ditujukan untuk memberikan bantuan kepada Yani,S.Pd yang mengajar di kelas IV; tanggal 25 Februari 2017, supervisi administrasi guru kelas ditujukan untuk memberikan bantuan kepada 
Yamini,S.Pd yang mengajar di kelas V, dan pada tanggal 27 Februari 2017, supervisi administrasi guru kelas ditujukan untuk memberikan bantuan kepada Amar Maruf,S.Pd yang mengajar di kelas VI.

\section{Pelaksanaan}

Kegiatan inti pelaksanaan supervisi administrasi guru kelas siklus II, baik peneliti maupun guru saling berusaha membangun karakter yang diinginkan sehingga tidak menghadapi hambatan seperti pada siklus sebelumnya. Pada awal kegiatan penelitian pada siklus II, peneliti mengumpulkan guru pada salah satu ruangan kelas, yaitu ruang kelas VI. Kegiatan ini dilaksanakan setelah jam efektif pembelajaran, tujuannya adalah agar tidak mengganggu kegiatan belajar mengajar siswa. Pada tahapan ini diberikan penjelasan tentang tata cara penilaian terhadap administrasi kelas yang telah dikumpulkan oleh guru-guru. Kegiatan ini dimaksudkan agar guru-guru semakin memahami tentang standar penyusunan administrasi kelas yang baku dan benar. Pada tahap tindakan, dilakukan diskusi tentang standar baku administrasi kelas yang harus dimiliki oleh para guru kelas. Para guru diminta berdiskusi tentang dokumen-dokumen yang harus ada dalam penyusunan administrasi kelas. Guru diminta membuat beberapa contoh tentang dokumen-dokumen wajib dan penunjang. Kegiatan dimaksudkan agar semakin mengerti dan paham tentang standar penyusunan administrasi kelas, serta mencari tahu secara mandiri kekurangan-kekurangan apa yang dimiliki oleh masingmasing guru dalam menyusun administrasi kelasnya masing-masing. Kegiatan selanjutnya adalah melaksanakan kegiatan penugasan kepada guru kelas mempersiapkan administrasi di kelasnya masing-masing dan dikumpulkan sebelum pertemuan kedua. Adapun waktu yang diberikan untuk mengumpulkan mempersiapkan administrasi kelas satu minggu dan dikumpulkan tiga hari setelah pertemuan kedua.

\section{Observasi}

Berdasarkan pengamatan peneliti, pada saat pelaksanaan pertemuan, nampak semua guru sudah mengerti tentang pengelolaan standar administrasi guru dengan baik. Hal tersebut nampak dari kesiapan para guru untuk mengumpulkan buku-buku wajib dan penunjang yang harus dikumpulkan untuk diberikan penilaian oleh peneliti dalam waktu 1 minggu. Berdasarkan hasil observasi diperoleh deskripsi bahwa semua guru dinyatakan telah mampu melaksanakan penyusunan administrasi kelas dengan benar. Secara klasikal peningkatan kemampuan guru dalam melaksanakan kegiatan penyusunan administrasi kelas telah memenuhi kriteria keberhasilan, karena baru memperoleh angka 158 dengan kriteria BAIK. Hal ini menunjukkan bahwa perolehan hasil tersebut sudah berada di atas kriteria keberhasilan yaitu minimal mendapat skor 141 atau lebih dengan kriteria minimal BAIK.

\section{PEMBAHASAN}

\section{Siklus I}

Dalam merefleksi hasil pelaksanaan tindakan siklus I, penulis beserta guru-guru melaksanakan diskusi. Melalui upaya ini diperoleh suatu kesepakatan 
mengenai keberhasilan dan kegagalan siklus I serta upaya untuk mengatasi agar tidak timbul kegagalan pada hal yang sama di siklus II. Secara umum, pertemuan pertama dengan guru-guru berjalan lancar, walaupun menyita waktu yang agak lama, serta dari hasil diskusi ada beberapa orang guru yang merasa belum siap dan keberatan untuk menyiapkan administrasi hanya dalam jangka waktu 1 minggu, tetapi setelah diberikan penjelasan mereka dapat mengikuti dan memahami tujuan pertemuan. Penilaian terhadap administrasi kelas dilakukan oleh pengawas sekolah setelah semua guru mengumpulkan administrasi kelas yang mereka miliki. Penilaian berpedoman kepada lembar penilaian yang disediakan.

Untuk mempertahankan dan meningkatkan keberhasilan siklus I, maka pada siklus II direncanakan tindakan sebagai dengan langkah peneliti yang sekaligus sebagai kepala sekolah yang bertugas menjadi supervisor meningkatkan pemahaman guru SD Negeri 1 Pandean baik dalam mengelola administrasi perencanaan pembelajaran, pelaksanaan pembelajaran, evaluasi pembelajaran, maupun upaya menindaklanjuti hasil pembelajaran. Pada saat proses pembelajaran sedang berlangsung, mulai dari menyusun rencana pembelajaran, melaksanakan pembelajaran, mengevaluasi, dan menindaklanjuti hasilnya, pengkaji sebagai kepala sekolah bertugas sebagai supervisor mendampingi para guru.

\section{Siklus II}

Kondisi awal, hasil observasi dan wawancara peneliti terhadap administrasi kelas yang dibuat guru (pada kondisi awal) dengan pelaksanaan kegiatan supervisi administrasi guru kelas, diperoleh informasi/data bahwa sebagian besar kinerja guru khususnya di SD Negeri 1 Pandean dalam penyusunan standar penyusunan administrasi kelas masih sangat rendah, bahkan ada beberapa orang guru yang hanya memiliki kurang dari 10 dokumen tentang standar penyusunan administrasi kelas dari jumlah keseluruhan sebanyak 40 dokumen. Hasil menunjukkan bahwa semua guru dinyatakan belum mempunyai kinerja yang baik dalam menyusun perangkat administrasi kelasnya masingmasing, guru kelas IV hanya memperoleh nilai 74 dengan kategori kurang, guru kelas V dan VI memperoleh nilai 79 dan 81 dan semuanya masuk dalam kategori kurang.

Kondisi siklus I setelah melaksanakan kegiatan awal penelitian, dan guna meningkatkan pemahaman guru tentang standar administrasi pengelolaan kelas, peneliti bersama-sama dengan guru-guru melaksanakan diskusi tentang pelaksanaan proses penyusunan administrasi kelas yang ideal. Dalam pelaksanaan diskusi tersebut di bahas tentang standar baku administrasi kelas yang harus dimiliki oleh para guru kelas, tentang dokumen-dokumen yang harus ada dalam penyusunan administrasi kelas. Guru dalam penyusunan administrasi kelas meningkat cukup signifikan dari kondisi awal. Di mana pada kondisi awal, seluruh guru dinyatakan belum mampu menyusun administrasi kelas dengan baik, namun setelah pelaksanaan kegiatan pada siklus I, 50\% guru atau sebanyak 3 orang dinyatakan meningkat kinerjanya terutama dalam kegiatan penyusunan administrasi kelas namun secara individual belum memenuhi kriteria 
keberhasilan, yaitu minimal mendapat kualifikasi hasil kinerja BAIK, namun secara umum dapat disimpulkan bahwa telah meningkat dari kondisi awal.

Pada refleksi siklus II dimulai dengan kegiatan mengumpulkan guru pada salah satu ruangan yang ada di sekolah melaksanakan kegiatan diskusi tentang standar baku administrasi kelas yang harus dimiliki oleh para guru kelas. Selanjutnya guru diminta berdiskusi tentang dokumen-dokumen yang harus ada dalam penyusunan administrasi kelas. Guru diminta membuat beberapa contoh tentang dokumen-dokumen wajib dan penunjang, sementara guru yang lain memperhatikan dan menanyakan apabila ditemukan kesulitan dan ketidakpahaman terhadap jenis dan macam dokumen-dokumen wajib dan penunjang pada administrasi kelas agar guru yang semakin mengerti dan paham tentang standar penyusunan administrasi kelas, serta mencari tahu secara mandiri kekurangan-kekurangan apa yang dimiliki oleh masing-masing guru dalam menyusun administrasi kelasnya masing-masing.

Dari hasil observasi dapat dianalisis bahwa kinerja guru dalam penyusunan administrasi kelas meningkat cukup signifikan pada siklus II, kinerja guru meningkat menjadi 3 guru atau $100 \%$. Hal ini menunjukkan bahwa kegiatan supervisi manajerial terbukti sangat efektif dalam meningkatkan kinerja guru khususnya pada kegiatan penyusunan administrasi kelas. Setelah melakukan serangkaian kegiatan pada tahap pelaksanaan siklus II, diperoleh simpulan bahwa semua guru mengerjakan administrasi kelas dengan baik. Sebagai langkah perbaikan, guru perlu dibekali untuk menyusun standar penyusunan administrasi kelas yang benar agar tujuan penelitian dapat tercapai, yaitu meningkatnya kinerja guru dalam penyusunan administrasi kelas; semua dokumen wajib maupun pendukung telah dibuat oleh para guru dengan baik walaupun masih ada beberapa kekurangan tetapi secara keseluruha kinerja dan kemampuan guru dalam penyusunan administrasi kelas meningkat dengan baik.

\section{KESIMPULAN}

Dari data-data hasil proses penelitian tindakan sekolah yang dilakukan di SD Negeri 1 Pandean Kecamatan Dongko Kabupaten Trenggalek dapat disimpulkan terjadi peningkatan kinerja guru dalam penyusunan administrasi kelas, di mana pada kondisi awal tidak ada guru yang mampu menyusun penyusunan administrasi kelas dengan baik hal tersebut dibuktikan dengan rendahnya hasil nilai rata-rata yang diperoleh guru-guru yaitu 78 dan hanya masuk dalam kategori kurang, pada siklus I meningkat cukup signifikan walaupun masih belum ada guru yang dinyatakan mampu menyusun administrasi kelas dengan baik, dengan peroleh nilai rata-rata secara klasikal sebesar 118 dan masuk dalam kriteria cukup dan pada siklus terakhir menjadi guru atau $100 \%$, dibuktikan dengan perolehan nilai secara klasikal sebesar 158 dalam kriteria nilai baik. Melihat data perolehan hasil penelitian dalam kegiatan penelitian tindakan sekolah ini, dapat disimpulkan bahwa supervisi administrasi guru kelas yang dilakukan oleh kepala sekolah terhadap 3 orang guru di SD Negeri 1 Pandean dinyatakan berhasil meningkatkan meningkatkan kinerja guru dalam penyusunan administrasi guru kelas.

342 BRILIANT: Jurnal Riset dan Konseptual Volume 2 Nomor 3, Agustus 2017 


\section{SARAN}

Saran yang dapat disampaikan bahwa agar kinerja guru semakin meningkat kepala sekolah hendaknya selalu memberi pengawasan baik langsung maupun tidak langsung salah satunya melalui kegiatan supervisi yang berkesinambungan dengan model yang disesuaikan dengan kondisi sekolah. Hendaknya para guru selalu dalam kondisi siap ketika melaksanakan kegiatan pembelajaran di dalam kelas agar pembelajaran semakin bermutu walaupun tidak ada pengawasan dari atasan.

\section{DAFTAR RUJUKAN}

Arikunto, Suharsimi. 2006. Dasar-Dasar Supervisi. Jakarta : PT Rineka Cipta. Depdikbud. 1990. Kamus Besar Bahasa Indonesia. Jakarta: Balai Pustaka Makawimbang, Jerry. 2013. Supervisi Klinis teori dan Pengukurannya. Bandung: Alfabeta.

Miles and Huberman, 1984. Qualitative Data Analysis. London: Sahe Publication. Mulyasa, E. 2004. Menjadi Guru Profesional Penciptakan Pembelajaran Kreatif dan Menyenangkan. Bandung : CV. Remaja Rosda Karya.

Mulyasa, E. 2006. Menjadi Guru Profesional dalam konteks menyukseskan MBS dan KBK. Bandung: CV. Remaja Rosda Karya.

Mulyasa,E. 2009. Menjadi Kepala Sekolah Profesional. Bandung: PT Remaja Rosda Karya.

Permendiknas RI Nomor 13 Tahun 2007. Tentang Standar Kompetensi Kepala Sekolah/Madrasah

Purwanto, Ngalim. 2009. Administrasi dan Supervisi Pendidikan. Bandung: PT Remaja Rosda Karya

Sulistiani dan Rosidah. 2003. Manajemen Sumber Daya Manusia Konsep dan Pengembangan dalam Kontek Organisasi Publik. Jakarta: Graham Ilmu

Suyati, Tri, dkk. 2009. Profesi Keguruan. Semarang: IKIP PGRI Semarang.

Undang-undang No. 20 Tahun 2003 Tentang Sistem Pendidikan Nasional. 